\title{
Lamotheoxyuris ackerti n. gen., n. comb. (Nematoda: Heteroxynematidae) parasite of Neotoma spp. (Rodentia: Muridae)
}

\author{
Lamotheoxyuris ackerti n. gen., n. comb. (Nematoda: Heteroxynematidae) \\ parásito de Neotoma spp. (Rodentia: Muridae)
}

\author{
JORGE FALCÓN-ORDAZ¹ , JESÚS A. FERNÁNDEZ² \& LUIS GARCÍA-PRIETO, * \\ ${ }^{1}$ Universidad Autónoma del Estado de Hidalgo, Centro de Investigaciones Biológicas, A.P. 1-69, Pachuca, 42001, \\ Hidalgo, México \\ 2 Department of Biological Sciences and Museum of Natural Science, Louisiana State University, Baton Rouge, \\ Louisiana, USA 70803 \\ ${ }^{3}$ Laboratorio de Helmintología, Instituto de Biología, Universidad Nacional Autónoma de México., Ap. Postal 70-153, \\ C.P. 04510, México D.F., México \\ ${ }^{*}$ Corresponding author: gprieto@ibiologia.unam.mx
}

\begin{abstract}
On the basis of the revision of the type material of Aspiculuris ackerti Kruidenier \& Mehra, 1959, and new specimens collected from Neotoma nelsoni Goldman, 1905 (Rodentia: Cricetidae), in Veracruz, Mexico, we herein describe a new genus (Lamotheoxyuris n. gen.), to which A. ackerti is transferred as Lamotheoxyuris ackerti (Kruidener \& Mehra, 1959) n. gen., n. comb. This new genus differs from all other genera included in Heteroxynematinae by the following main traits: 1) mouth surrounded by six lips; 2) extension of lateral alae reduced; and 3) lack of caudal alae.
\end{abstract}

Key words: Aspiculuris ackerti, Mexico, Nematoda, Rodentia, USA.

\section{RESUMEN}

Con base en la revisión del material tipo de Aspiculuris ackerti Kruidenier y Mehra, 1959 y de nuevos ejemplares recolectados en Neotoma nelsoni Goldman, 1905 (Rodentia: Cricetidae), en Veracruz, México, se describe un nuevo género (Lamotheoxyuris n. gen.), al que A. ackerti es transferido como Lamotheoxyuris ackerti (Kruidener y Mehra, 1959) n. gen., n. comb. Este nuevo género se distingue de todos los demás géneros incluidos en Heteroxynematinae por las siguientes características: 1) presencia de seis labios rodeando la boca; 2) extensión reducida del ala lateral; y 3 ) carencia de ala caudal.

Palabras clave: Aspiculuris ackerti, México, Nematoda, Rodentia, USA.

\section{INTRODUCTION}

Aspiculuris ackerti Kruidenier \& Mehra, 1959 was described as a parasite of Neotoma albigula Hartley, 1894 and Neotoma cinerea Ord, 1815 in Arizona (Kruidenier \& Mehra 1959). Since then, the validity of its classification has been questioned several times. Hugot (1980) pointed out that A. ackerti does not possess the generic characteristics to support its placement in the genus Aspiculuris Schulz, 1924. In a re-description of $A$. ackerti, Miller \& Schmidt (1982) found some discrepancies with respect to the original description, i.e., different number of caudal papillae and morphology of caudal alae. Finally, in agreement with Hugot (1980), Inglis et al. (1990) considered this nematode as species dubium. Based on the re-examination of type material of this nematode species and in new specimens collected in Veracruz, Mexico from Nelson's woodrat Neotoma nelsoni Goldman, 1905, we conclude that $A$. ackerti belongs to a new genus, which is herein described.

The type host of $A$. ackerti ( $N$. albigula) is distributed from southeastern California and southeastern Utah to central Texas and from northeastern Michoacán to Hidalgo, Mexico (Macedo \& Mares 1988). Other host of this nematode species, $N$. cinerea is found in mountainous areas from the southern Yukon and the westernmost Northwest Territories, south through British Columbia and western 
Alberta to northern California, Arizona and New Mexico, and as far east as the western portion of North Dakota (Smith 1997). Finally, N. nelsoni, which also hosts $A$. ackerti, is an endemic species of the Oriental Basin of Mexico.

\section{METHODS}

One specimen of $N$. nelsoni (Rodentia: Cricetidae) was trapped in the wild using standard methods approved by the American Society of Mammalogists (Gannon et al. 2007). This specimen was collected on 22 June 2007 from El Frijol Colorado, Municipality of Perote, in the state of Veracruz $\left(19^{\circ} 34^{\prime} 20^{\prime \prime} \mathrm{N}, 97^{\circ} 23^{\prime} 01^{\prime}\right.$ ' W, 2,435 masl) and examined for parasites. This locality is characterized by rocky hills with cactus pear, catclaw, agave and yucca. Intestinal nematodes were fixed in 70 $\%$ ethanol and cleared with lactophenol for morphometric study. For comparative purposes the following specimen from the U. S. National Parasite Collection (USNPC), Beltsville, Maryland, was examined: Aspiculuris ackerti Kruidener \& Mehra, 1959 [USNPC 056163 (type specimens), 075506 and 088077].

Drawings and measurements were made with a Zeiss microscope equipped with a drawing tube. For scanning electron microscopy (SEM) study, nematodes were dehydrated in graded series ethyl alcohol dilutions and critical-point dried with carbon dioxide. Specimens were coated with a gold-palladium mixture and examined in a Hitachi S-2460N scanning electron microscope at $15 \mathrm{kV}$. Range is followed by the mean and standard deviation; sample size (n) is provided in parentheses. The host was obtained under the collecting permit FAUT-0002 issued to Fernando Cervantes Reza and is housed at the Museum of Natural Science (Louisiana State University) as specimen number LSUMZ 36663. Voucher specimens of parasites were deposited in the Colección Nacional de Helmintos (CNHE), Instituto de Biología, Universidad Nacional Autónoma de México, Mexico City.

\section{RESULTS}

\section{Description of the genus}

Lamotheoxyuris $n$. gen

Diagnosis: Oxyurida, Heteroxinematidae, Heteroxynematinae. The worms are small in size. Males are shorter than females. Cephalic vesicle present; cervical alae present, extending from the cephalic region to the midbody in males and before the vulva in females; each cervical alae have two crests (sensu Hugot 1980) in cross section. Lateral alae are reduced in the both sexes. A ventral ala is present in males, beginning at the mid-body region and ending before the cloaca. The mouth is surrounded by six lips, one pair of lateral "epaulettes" with two amphids and four labial papillae. Males without caudal alae. Gubernaculum and spicules are absent. Ten caudal papillae are arranged as follows: one pair precloacal, one pair adcloacal, a single median postcloacal papilla closely associated with the cloaca, one posterior pair followed by one single median papilla, and one additional posterior pair.

\section{Taxonomic summary}

Type and only known species: Lamotheoxyuris ackerti (Kruidener \& Mehra, 1959) n. comb., parasitizing the intestine of $N$. albigula, 1894 from Coconimo Co., Arizona, United States of America.

Other records: ex $N$. cinerea from Colorado and Wyoming. N. albigula from New Mexico, and $N$. nelsoni from Veracruz, Mexico.

Etymology: The genus is named after Dr. Marcos Rafael Lamothe-Argumedo in commemoration of his $50^{\text {th }}$ anniversary as a scientific researcher in Helminthology.

\section{Remarks}

Following Petter \& Quentin (1976), our specimens are included in Heteroxynematidae: Heteroxynematinae because the last pair of male postcloacal papillae is isolated near the caudal extremity, the glandular portion of the ovijector is never in the form of an enlarged ring at the distal end of the muscular vagina vera, eggs lacking operculum, and the pharyngeal and buccal structures are simples. To date, Heteroxynematinae comprises 10 genera distributed worldwide (Erkulov 1975, Petter \& Quentin 1976, Mas-Coma \& Esteban 1982). Two of these 10 genera can be distinguished from the new genus because they are parasites of birds: Eudromoxyura Anderson \& Prestwood, 1972 and Syphaciella Mönnig, 1924, while Lamotheoxyuris infects rodents; in addition, Eudromoxyura has an intestinal caecum behind the esophageal bulb, which is absent in Lamotheoxyuris, and three well developed trilobed lips with small interlabia (vs. six lips without interlabia in the new genus) (Anderson \& Prestwood 1972); likewise, the presence of triangular teeth in the vestibule as well as gubernaculum, spicules, and caudal alae allow to differentiate 
Syphaciella from Lamotheoxyuris, which lacks these structures (Petter \& Quentin 1976).

The other eight genera included in Heteroxynematinae (Aspiculuris Schulz, 1924; Dermatopallarya Skrjabin, 1924; Dentostomella Schulz \& Krepkogorskaja, 1932; Fastigiuris Babaev, 1966; Heteroxynema Hall, 1916; Ivaschkinonema Erkulov, 1975; Kahmannia MasComa \& Esteban, 1982, \& Rauschoxyuris Quentin, 1975) parasitize mammals, as does the new genus. However, two of them (Dentostomella and Kahmannia) lack cervical alae (present in Lamotheoxyuris), and have esophageal teeth and a single spicule (both characteristics absent in the new genus) (Petter \& Quentin 1976, Skrjabin 1982, Mas-Coma \& Esteban 1982). The species included in the remaining six genera that parasitize mammals have cervical alae like Lamotheoxyuris ackerti. However, the new genus differs from all these genera by the following main characteristics: Dermatopallarya have three lips and a defined buccal cavity instead of six lips and a mouth opening directly to the esophagus, as in the new genus; in addition, males of Dermatopallarya possess two ventral cuticular swellings, which are absent in the new genus (Petter \& Quentin 1976, Skrjabin 1982); the esophageal bulb in Fastigiuris is reduced or absent whereas this structure is well developed in the new genus; also, the cervical alae in Fastigiuris are markedly bent in the ventral region (Petter \& Quentin 1976) while the cervical alae are straight in the specimens described in this study. Likewise, Lamotheoxyuris can be differentiated from Heteroxynema because males of this later genus have a precloacal pseudosucker, gubernaculum, and a spicule (Petter \& Quentin 1976, Hugot \& Sutton 1989), which are all lacking in the new genus. Ivaschkinonema possesses four differentiated lips and caudal rings (Erkulov 1975), whereas Lamotheoxyuris has six lips and lacks caudal rings. Finally, Rauschoxyuris has a precloacal denticulate crest (Quentin 1975), that is absent in the new genus.

The new genus most closely resembles to Aspiculuris. Nevertheless, both genera can be distinguished based on the following traits: 1) Aspiculuris has caudal alae (absent in Lamotheoxyuris); 2) lateral alae in Aspiculuris run along the body, while the lateral alae only reach the mid-body region in the new genus; 3 ) cervical alae in Aspiculuris narrow posteriorly to give a spearhead-like or an arrowhead-like outline to the cephalic end, differentiating it from lateral alae; in Lamotheoxyuris, the cervical alae are continuous with the lateral alae, with no superficial distinction; 4) cross sections of cervical and lateral alae in our material, showed the same morphology, being constituted by two crests along its extension; in Aspiculuris spp., cross sections of cervical alae showed two crests, while the lateral alae had only one crest [for examples, see Figs. 1C, 1D, and 1E for Aspiculuris tetraptera (Nitzsch, 1821), and Figs. 3J, 3K, 3L, and 3M for Aspiculuris africana Quentin, 1966 in Hugot (1980); finally, 5) the mouth in Aspiculuris is surrounded by three undivided lips, while $L$. ackerti possesses six lips that are clearly differentiated by SEM. Observations of the anterior end of $A$. ackerti in face view, made by Miller \& Schmidt (1982) with light microscopy, could not establish the true number of lips.

\section{Description of the species}

Lamotheoxyuris ackerti (Kruidener \& Mehra, 1959) n. gen., n. comb.

(Figs. 1-3)

Male: Based on six mature specimens. Body small, cylindrical. Length $3.10-3.74 \mathrm{~mm}$ (3.58 $\mathrm{mm} \pm 0.29 \mathrm{~mm}, \mathrm{n}=6)$; width 154-182 $\mu \mathrm{m}(163$ $\mu \mathrm{m} \pm 11 \mu \mathrm{m}, \mathrm{n}=6)$ at mid-body. Cephalic vesicle 98-126 $\mu \mathrm{m}$ long $(117 \mu \mathrm{m} \pm 11 \mu \mathrm{m}, \mathrm{n}=6)$ by $84-112 \mu \mathrm{m}$ wide $(98 \mu \mathrm{m} \pm 9 \mu \mathrm{m}, \mathrm{n}=6)$. Total esophagus length 291-360 $\mu \mathrm{m}(337 \mu \mathrm{m} \pm 26$ $\mu \mathrm{m}, \mathrm{n}=6)$; esophageal bulb 105-132 $\mu \mathrm{m}$ (121 $\mu \mathrm{m} \pm 9 \mu \mathrm{m}, \mathrm{n}=6)$ long by 54-66 $\mu \mathrm{m}(60 \mu \mathrm{m} \pm 4$ $\mu \mathrm{m}, \mathrm{n}=6$ ) wide. Distance from anterior end to nerve ring 141-150 $\mu \mathrm{m}(146 \mu \mathrm{m} \pm 4 \mu \mathrm{m}, \mathrm{n}=6)$, to excretory pore $717-735 \mu \mathrm{m}(723 \mu \mathrm{m} \pm 10 \mu \mathrm{m}$, $\mathrm{n}=3$ ). Excretory pore posterior to junction of esophageal bulb and intestine. Cervical alae beginning $30-36 \mu \mathrm{m}(26 \mu \mathrm{m} \pm 3 \mu \mathrm{m}, \mathrm{n}=3)$ from anterior end; it will continue with a short lateral alae which ends at midbody. Distance from cloaca to tip of tail $87-117 \mu \mathrm{m}(108 \mu \mathrm{m} \pm$ $11 \mu \mathrm{m}, \mathrm{n}=6)$. Ten caudal papillae arranged as follow: one precloacal pair, one adcloacal pair, a single medial postanal pair closely associated with cloaca, one posterior pair followed by one single median (located between two long and straight cuticular thickenings), and one additional posterior pair. 

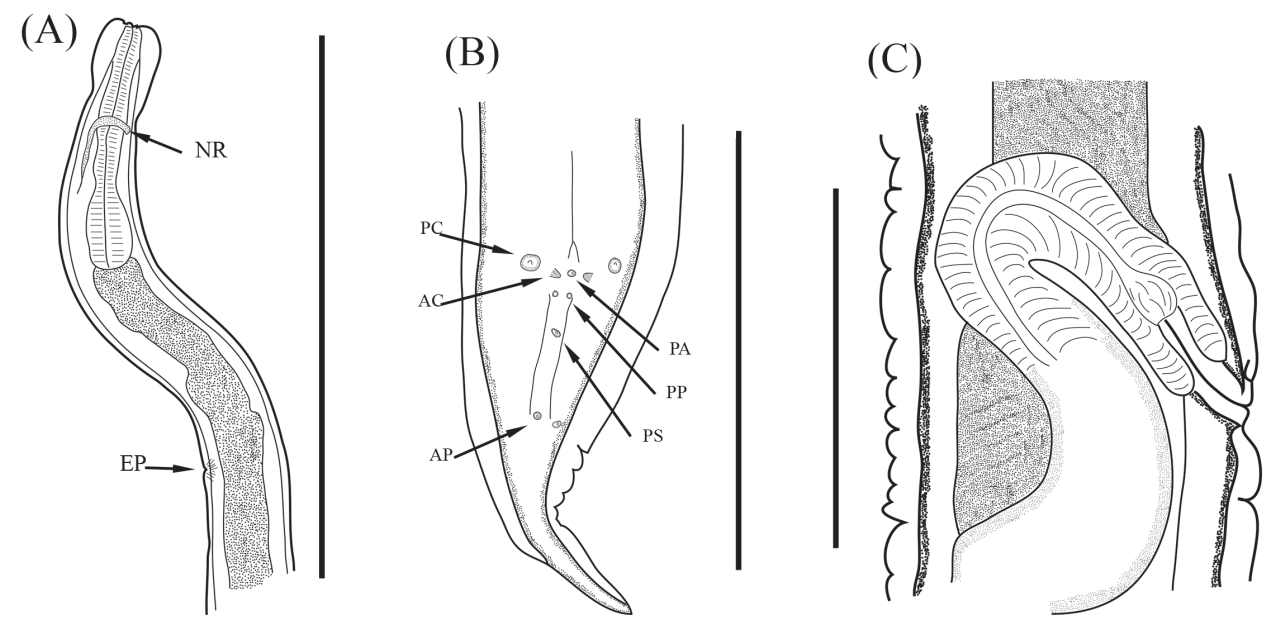

(D)

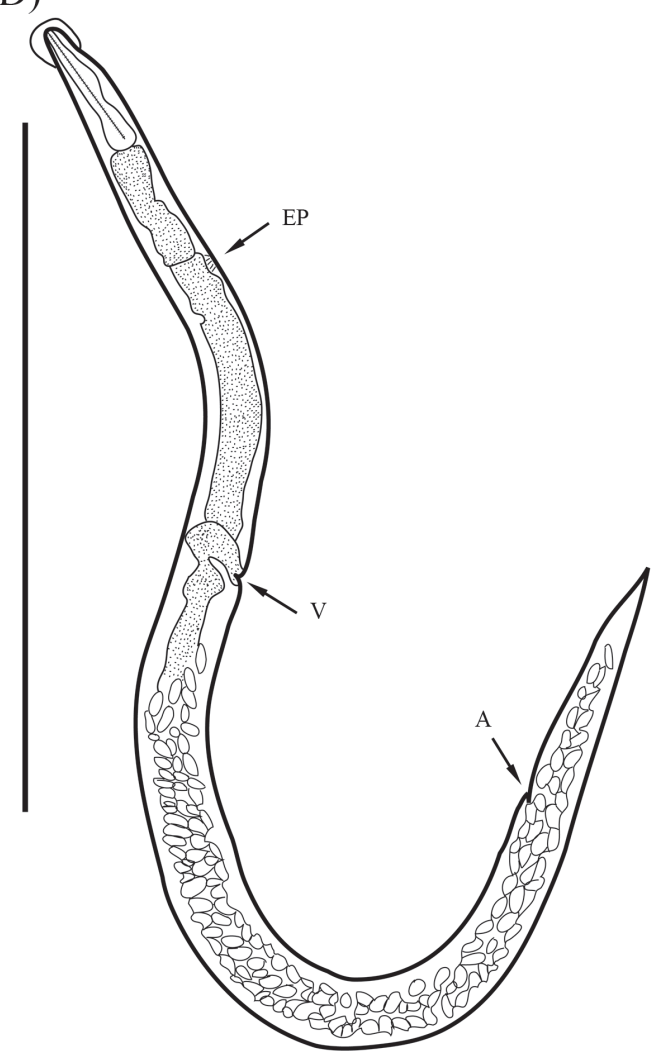

(E)

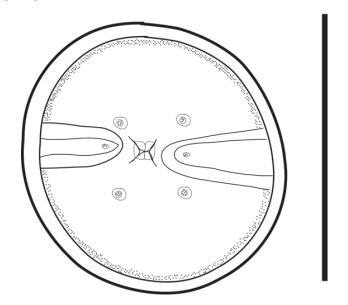

(F)

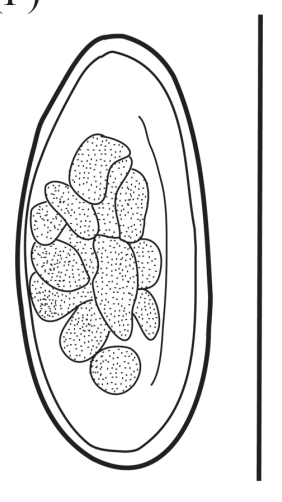

Fig. 1: Lamotheoxyuris ackerti n. gen., n. comb., from Neotoma nelsoni. Male: A) Anterior end, lateral view $(\mathrm{NR}=$ nerve ring; $\mathrm{EP}=$ excretory pore $) . \mathrm{Bar}=1.0 \mathrm{~mm} ; \mathrm{B})$ Detail of posterior end of male, arrangement of caudal papillae $(\mathrm{PC}=1$ precloacal pair; $\mathrm{AC}=1$ adcloacal pair; $\mathrm{PA}=$ single medial postanal; $\mathrm{PP}=1$ posterior pair; $\mathrm{PS}=1$ single median; $\mathrm{AP}=1$ additional posterior pair). $\mathrm{Bar}=250 \mu \mathrm{m}$. Female: $\mathrm{C}$ ) Ovejector region. Bar $=200 \mu \mathrm{m} . \mathrm{D})$ Entire, lateral view $(\mathrm{EP}=$ excretory pore; $\mathrm{V}=$ vulva; $\mathrm{A}=\mathrm{anus}) . \mathrm{Bar}=2.0 \mathrm{~mm} . \mathrm{E})$ In face view showing lips, papillae and "epaulettes". Bar = $100 \mu \mathrm{m} . \mathrm{F})$ Eggs. Bar $=100 \mu \mathrm{m}$.

Lamotheoxyuris ackerti n. gen., n. comb., de Neotoma nelsoni. Macho: A) Extremo anterior, vista lateral (NR = anillo nervioso; $\mathrm{EP}=$ poro excretor). Escala $=1.0 \mathrm{~mm}$; B) Detalle del extremo posterior del macho, disposición de las papilas caudales $(\mathrm{PC}=1$ par precloacal; $\mathrm{AC}=1$ par adcloacal; $\mathrm{PA}=$ papila postanal media; $\mathrm{PP}=1$ par postcloacal $; \mathrm{PS}=1$ papila media; $\mathrm{AP}=1$ par posterior adicional. Escala $=250 \mu \mathrm{m}$. Hembra: C) Región del Ovijector. Escala $=200 \mu \mathrm{m}$. D) Ejemplar completo, vista lateral $(\mathrm{EP}=$ poro excretor; $\mathrm{V}=$ vulva; $\mathrm{A}=\mathrm{ano})$. Escala $=2.0 \mathrm{~mm}$. E) Vista frontal mostrando los labios, papilas y "epaulettes". Escala $=100 \mu \mathrm{m}$. F) Huevos. Escala $=100 \mu \mathrm{m}$. 
(A)
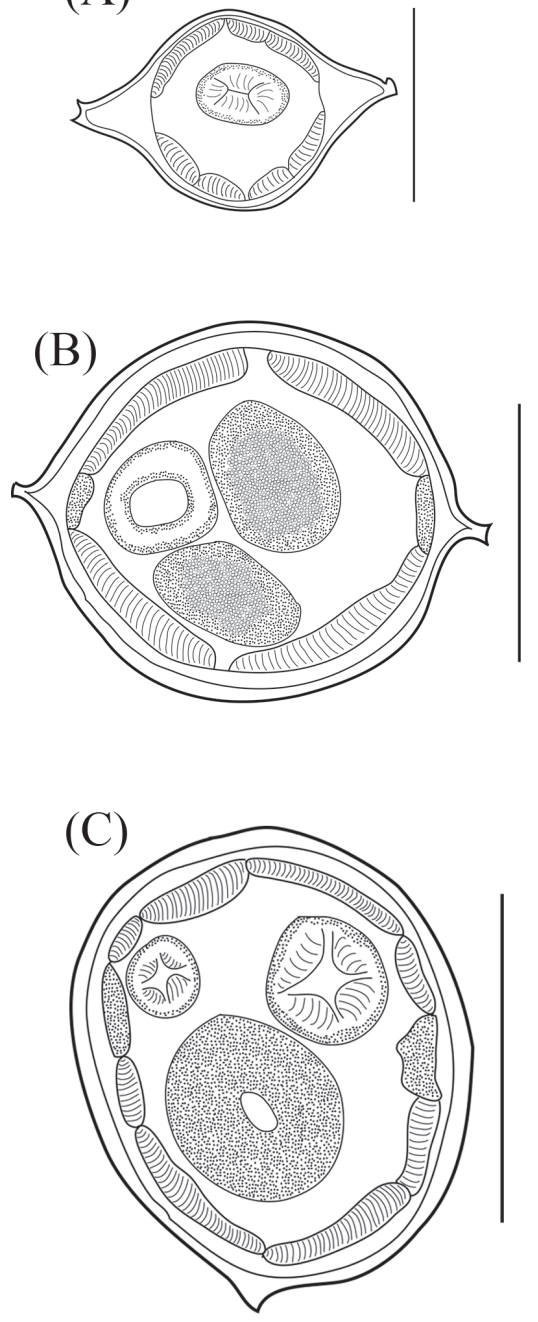

(D)

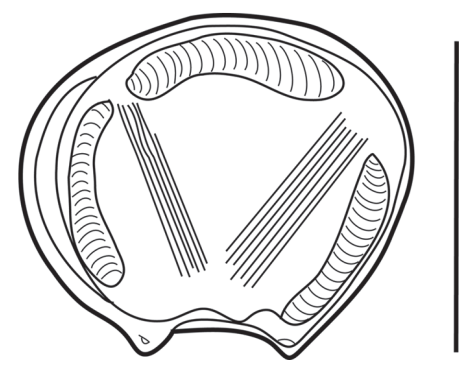

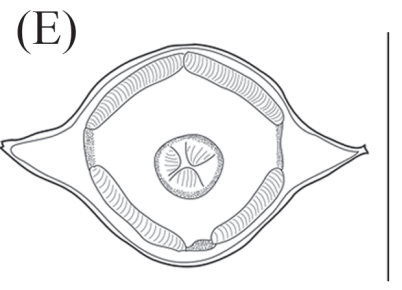
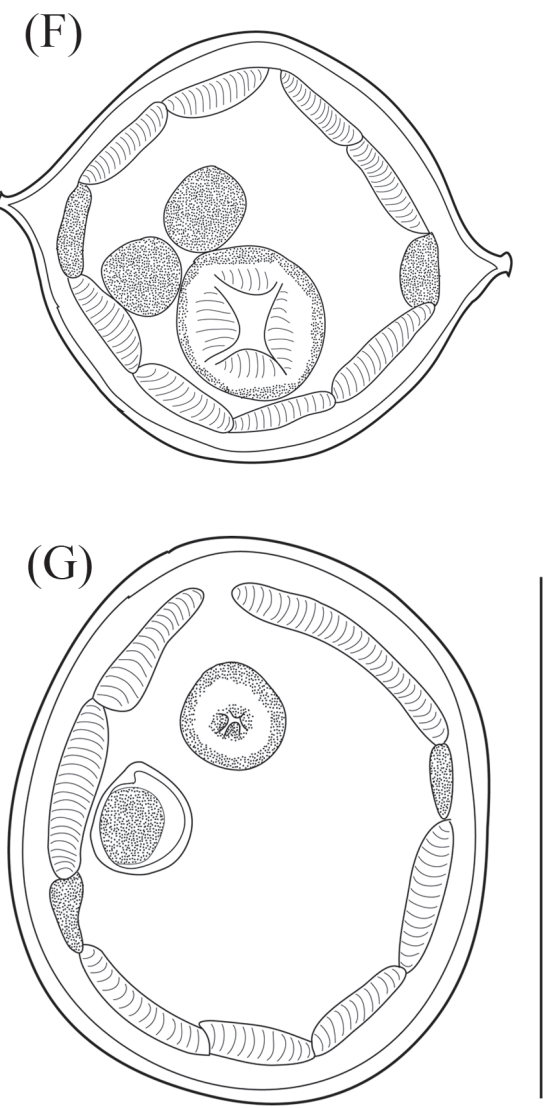

Fig. 2: Lamotheoxyuris ackerti n. gen., n. comb., from Neotoma nelsoni. Male, cross section: A) Esophagus level. $\mathrm{Bar}=100 \mu \mathrm{m} . \mathrm{B}$ ) End of alae. Bar $=100 \mu \mathrm{m}$. C) Caudal region $150 \mu \mathrm{m}$. D) Postcloacal region. Bar $=100$ $\mu \mathrm{m}$. Female cross section: E) Esophagus level. Bar $=150 \mu \mathrm{m}$. F) Close to the vulva. Bar $=200 \mu \mathrm{m}$. G) Ovejector level. Bar $=200 \mu \mathrm{m}$.

Lamotheoxyuris ackerti n. gen., n. comb., de Neotoma nelsoni. Macho, corte transversal: A) A nivel del esófago. Escala $=100 \mu \mathrm{m}$. B) A nivel del final del ala lateral. Escala $=100 \mu \mathrm{m}$. C) En la región caudal. Escala $=$ $150 \mu \mathrm{m}$. D) En la región postcloacal. Escala $=100 \mu \mathrm{m}$. Hembra, corte transversal: E) A nivel del esófago. escala $=150 \mu \mathrm{m} . \mathrm{F})$ Cercano a la vulva. Escala $=200 \mu \mathrm{m} . \mathrm{G})$ A nivel del ovijector. Escala $=200 \mu \mathrm{m}$. 

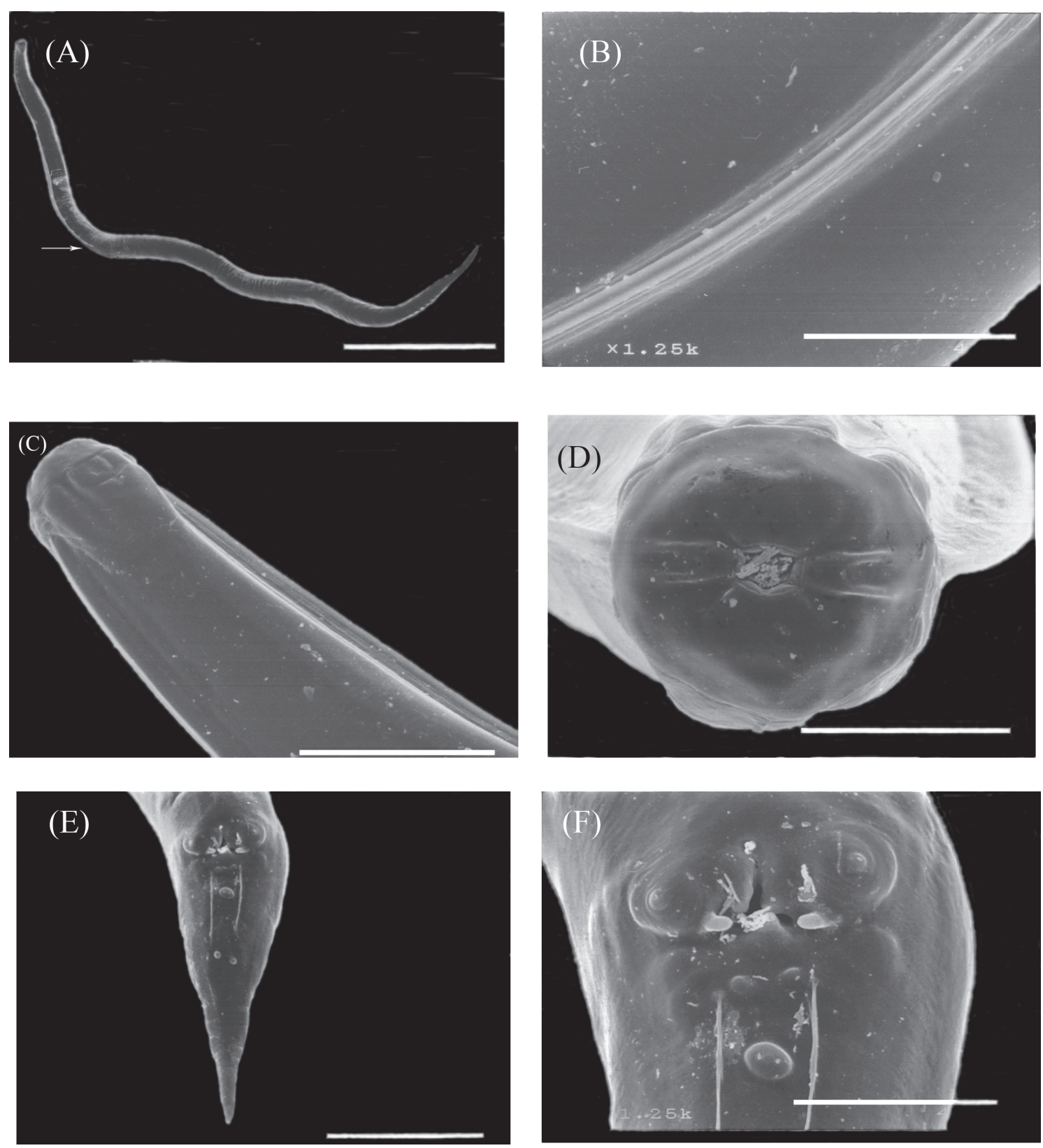

Fig. 3: Lamotheoxyuris ackerti n. gen., n. comb., from Neotoma nelsoni. Male: A) Total view. Bar = 1 mm; white arrow indicates final of lateral alae; B) Lateral ala, lateral view. Bar $=40 \mu \mathrm{m}$. C) Detail of anterior end, dorsal view. Bar $=100 \mu \mathrm{m}$. D) Mouth apical view Bar $=40 \mu \mathrm{m}$; E) Caudal sessile papillae, ventral view. Bar = $100 \mu \mathrm{m}$. F) Detail of caudal papillae. Bar $=40 \mu \mathrm{m}$.

Lamotheoxyuris ackerti n. gen., n. comb., de Neotoma nelsoni. Macho: A) Vista total. Escala = $1 \mathrm{~mm}$; la flecha blanca indica el final del ala lateral; B) ala lateral, vista lateral. Escala $=40 \mu \mathrm{m}$. C) Detalle del extremo anterior, vista dorsal. Escala $=100$ $\mu \mathrm{m}$. D) Boca, vista apical. Escala $=40 \mu \mathrm{m}$; E) Papilas caudales sésiles, vista ventral. Escala $=100 \mu \mathrm{m}$. F) Detalle de las papilas caudales. Escala $=40 \mu \mathrm{m}$.

Female: Based on 11 mature specimens. Length at mid-body $4.558-5.663 \mathrm{~mm}(5.045 \mathrm{~mm}$ $\pm 0.33 \mathrm{~mm}, \mathrm{n}=11)$; width $21-224 \mu \mathrm{m}(218 \mu \mathrm{m} \pm$ $7 \mu \mathrm{m}, \mathrm{n}=11)$. Cephalic vesicle 112-168 $\mu \mathrm{m}$ long $(139 \mu \mathrm{m} \pm 13 \mu \mathrm{m}, \mathrm{n}=11)$ by $112-126 \mu \mathrm{m}$ wide $(115 \mu \mathrm{m} \pm 8, \mathrm{n}=11)$. Total esophagus length 369-465 $\mu \mathrm{m}(404 \mu \mathrm{m} \pm 27 \mu \mathrm{m}, \mathrm{n}=11)$; esophageal bulb $120-150 \mu \mathrm{m}(135 \mu \mathrm{m} \pm 10 \mu \mathrm{m}$, 
$\mathrm{n}=11)$ long, 66-84 $\mu \mathrm{m}(77 \mu \mathrm{m} \pm 5 \mu \mathrm{m}, \mathrm{n}=11)$ wide. Distance from anterior end to nerve ring 135-156 $\mu \mathrm{m}(145 \mu \mathrm{m} \pm 6 \mu \mathrm{m}, \mathrm{n}=11)$, to excretory pore $639-804 \mu \mathrm{m}(720 \mu \mathrm{m} \pm 50 \mu \mathrm{m}, \mathrm{n}$ $=10)$. Cervical alae beginning 27-45 $\mu \mathrm{m}(33 \mu \mathrm{m}$ $\pm 6 \mu \mathrm{m}, \mathrm{n}=9$ ) from anterior end; it will continue with a short lateral alae which ends before to vulva. Vulva pre-equatorial, opening $1.6-2 \mathrm{~mm}(1.79 \mathrm{~mm} \pm 0.128 \mathrm{~mm}, \mathrm{n}=10)$ from anterior end. Ovejector 249-264 $\mu \mathrm{m}(256 \mu \mathrm{m} \pm$ $11 \mu \mathrm{m}, \mathrm{n}=2$ ) long. Distance from caudal extremity to anus 591-660 $\mu \mathrm{m}(618 \mu \mathrm{m} \pm 26$ $\mu \mathrm{m}, \mathrm{n}=6)$; eggs $78-90 \mu \mathrm{m}(86 \mu \mathrm{m} \pm 4 \mu \mathrm{m})$ long by $30-39 \mu \mathrm{m}(34 \mu \mathrm{m} \pm 2 \mu \mathrm{m})$ wide $(\mathrm{n}=66$ eggs).

\section{Taxonomic summary}

Type host: Neotoma albigula Hartley, 1894; (Rodentia: Cricetidae).

Site of infection: Intestine.

Type locality: Coconimo County, Arizona.

Other hosts: Neotoma cinerea (Ord, 1815);

N. nelsoni Goldman, 1905.

Other localities: Weld Co., Colorado and Laramie Co., Wyoming (Miller \& Schmidt 1982); Sorocco Co., New Mexico (USNPC 88077, identified by M. D. Dailey); $3 \mathrm{~km} \mathrm{~S} \mathrm{El}$ Frijol Colorado $\left(19^{\circ} 34^{\prime} 20^{\prime \prime} \mathrm{N}, 97^{\circ} 23^{\prime} 0.7^{\prime \prime} \mathrm{W}\right.$, elevation: 2,435 m), Perote, Veracruz, Mexico.

Specimens deposited: CNHE 6839.

Synonym: Aspiculuris ackerti Kruidener \& Mehra, 1959.

\section{DISCUSSION}

Aspiculuris ackerti was described by Kruidener \& Mehra (1959) who justified the inclusion of this species in Aspiculuris based on the presence of cervical alae with a gradual anterior-posterior narrowing (as in A. asiatica Schulz, 1927) and the presence of "two deep notches each" in the caudal alae of males (Kruidener \& Mehra 1959, pp. 148). This species was re-described by Miller \& Schmidt (1982) who pointed out that the cervical alae narrow smoothly and continue posterior as narrow lateral alae.

Unlike Kruidener \& Mehra (1959), Miller \& Schmidt (1982, pp. 112) observed only one deep notch in the caudal alae of males, which gives "the superficial appearance of being paired" to the alae. Based on our examination of the type material of $A$. ackerti (USNPC 056163) and new specimens from $N$. nelsoni from Mexico, we determined that caudal alae do not exist in this species. What appeared to be caudal alae to Kruidener \& Mehra (1959) and Miller \& Schmidt (1982) look more like cuticular inflation under light microscopy. Subsequently SEM examination of these structures and cross sections of the body at this level showed that males of $A$. ackerti lack caudal alae altogether.

This is the first report of a helminth parasite occurring in Nelson's woodrat $N$. nelsoni, which is endemic and endangered species in Mexico. Prior to this study, distribution of this woodrat was restricted to only three locations in the states of Veracruz and Puebla (Hall \& Dalquest 1963, Hall 1981, González-Christen et al. 2002; González-Ruíz et al. 2006). Herein, we reported a fourth locality for this species in Veracruz, Mexico.

\section{ACKNOWLEDGMENTS}

We thank Fernando Cervantes for providing collection permits. Eric Hoberg and Patricia Pillit, from USNPC, have kindly lent us the type specimens of $A$. ackerti. Juan Carlos Winfield-Pérez helped collecting rodents in the field and Berenit Mendoza-Garfias for assisting in processing samples for SEM. The Department of Biological Sciences and the Museum of Natural Science, Louisiana State University and the Instituto de Biología of the Universidad Nacional Autónoma de México provided financial support for field work. We thank Mark S. Hafner for critical comments on the manuscript. This paper was conducted while J.F.O. was a Posdoctoral Fellow in the Laboratorio de Morfologia Animal, Centro de Investigaciones Biológicas, Universidad Autónoma del Estado de Hidalgo, supported by a fellowship grant: "Estancias posdoctorales y sabáticas vinculadas al fortalecimiento de la calidad del posgrado nacional 2008", from Consejo Nacional de Ciencia y Tecnología (CONACyT).

\section{LITERATURE CITED}

ANDERSON RC \& AK PRESTWOOD (1972) Eudromoxyura elonbyrdi n. g., n. sp. (Nematoda: Oxyuroidea) from crested tinamou (Eudromia elegans). Canadian Journal of Zoology 50: 297300 . 
ERKULOV K (1975) A new genus and species of nematodes from Alticola argentatus in southern Kirgizia, USSR. Gel'mintologicheskie issledovaniya v Kirgizii (Russia) 14: 50-53

GANNON WL, RS SIKES \& THE ANIMAL CARE AND USE COMMITTEE OF THE AMERICAN SOCIETY OF MAMMALOGISTS (2007) Guidelines of the American Society of Mammalogists for the use of wild animals in research. Journal of Mammalogy 88: 809-823.

GONZÁLEZ-CHRISTEN A, S GAONA, \& G LÓPEZORTEGA (2002) Registros adicionales de mamíferos para el Estado de Veracruz, México. Vertebrata Mexicana (Mexico) 11: 9-16.

GONZÁLEZ-RUÍZ N, J RAMÍREZ-PULIDO \& HH GENOWAYS (2006) Geographic distribution, taxonomy, and conservation status of Nelson's woodrat (Neotoma nelsoni) in Mexico. Southwestern Naturalist 51: 112-116.

HALL ER (1981) The mammals of North America. John Wiley and Sons, New York, USA

HALL ER \& WW DALQUEST (1963) The mammals of Veracruz. University of Kansas Publications 14: 165-362.

HUGOT JP (1980) Sur le genre Aspiculuris Schulz, 1924 (Nematoda, Heteroxynematidae), oxyures parasites de rongeurs Muroidea. Bulletin du Museum National d'Histoire Naturelle 2: 723735.

HUGOT JP \& C SUTTON (1989) Contribution à la connaissance de la faune parasitaire d' Argentine, XV. Etude morphologique de Heteroxynema (Cavioxyura) viscaciae n. $\mathrm{sp}$. (Nematoda, Heteroxynematidae) parasite de Lagidium viscacia boxi (Mammalia, Rodentia). Systematic Parasitology 13: 111-120.

INGLIS WG, EA HARRIS \& JW LEWIS (1990) The new species of the nematode genus Aspiculuris

Associate Editor: Mario George-Nascimento

Received March 9, 2009; accepted December 3, 2009
Schulz, 1924 from Aethomys namaquensis (Mammalia: Rodentia) in the Kruger National Park, South Africa. Systematic Parasitology 17: 231-236.

KRUIDENER FJ \& KN MEHRA (1959) Aspiculuris ackerti, n. sp., (Nematoda: Oxyuroide) from the woodrats of Arizona. Proceedings of the Helmintological Society of Washington 26: 147150.

MACEDO RH \& MA MARES (1988) Neotoma albigula. Mammalian Species 310: 1-7.

MAS-COMA S \& JG ESTEBAN (1982) Kahmannia eliomydis n. gen., n. sp. (Nematoda: Heteroxynematidae) un intestinale parastite d' Eliomys quercinus (L. 1766) (Rodentia: Glididae) à Minorque (Baléares). Annales de Parasitologie Humaine et Comparée 57: 487-495.

MILLER GE \& GD SCHMIDT (1982) Helminths of Bushy-tailed Wood Rats, Neotoma cinerea subspp., from Colorado, Idaho and Wyoming. Proceedings of the Helmintological Society of Washington 49: 109-117.

PETTER AJ \& JC QUENTIN (1976) Keys to genera of the Oxyuroidea. In: Anderson RC, AG Chabaud \& S Willmott (eds) CIH Keys to the nematode parasites of vertebrates: 1-30. Common Wealth Agricultural Bureaux, Farnham Royal, Bucks, UK.

QUENTIN JC (1975) Essai de classification des oxyures Heteroxynematidae. Memoires du Museum National d' Histoire Naturelle 94: 51-96.

SMITH FA (1997) Neotoma cinerea. Mammalian Species 564: 1-8.

SKRJABIN KI (1982) Key to parasitic Nematode. Oxyurata and Ascaridata. United States Department of Agriculture and The National Science Fundation, Washington DC. 